\title{
分子シャペロンの遺伝子異常により引き起こされる血小板増多
}

荒木真理人*

\section{Thrombocytosis caused by abnormal molecular chaperone}

\author{
Marito ARAKI
}

要約：巨核球の腫瘍性増殖による末梢血中の血小板増多を呈する本態性血小板血症の大部分の症例では, サイ トカイン受容体に結合するチロシンキナーゼJAK2, トロンボポエチン（thrombopoietin: TPO）受容体 MPL, 分 子シャペロンCALRに，相互排他的な遺伝子変異が見いだされる.JAK2 と MPL 変異はいずれも機能獲得型変 異であり, TPO シグナルの恒常的な活性化による巨核球の異常増殖によって, 血小板増多が生じる. 一方で, これらの中で最後に変異が見つかった calreticulin（CALR）遺伝子は，それまでTPO シグナルや巨核球分化な どとの関連が全く報告されておらず，CALR 変異が血小板増多を引き起こすメカニズムは不明であった．本論 文では，筆者らがこれまでに明らかにしてきた，変異型 CALR 蛋白質によるTPO シグナル伝達経路の恒常的な 活性化の分子メカニズムについて概説する.

Key words: essential thrombocythemia, myeloproliferative neoplasm, calreticulin, chaperone, MPL

\section{1. 本態性血小板血症}

血小板増多症の 1 つである本態性血小板血症 （essential thrombocythemia: ET）は，骨髄増殖性腫瘍 (myeloproliferative neoplasms: MPN) に分類される造 血器腫瘍である. ET は, 造血幹細胞に体細胞変異が 生じ，変異を有した造血幹細胞が増幅した結果，血 小板産生を行う巨核球が異常に増加することで発症 すると考えられている．2005年に，ETを含む多く の MPN 患者に共通して, サイトカイン受容体シグ ナルを伝達するチロシンキナーゼJAK2 に機能獲得 型の体細胞変異が見いだされた（図 1 $)^{1-4)}$. さらに 2006 年には, JAK2 変異陰性の ET 患者の一部におい て, 血小板産生を促す造血因子トロンボポエチン （thrombopoietin: TPO）の受容体 MPL に機能獲得型 の体細胞変異が見いだされた $(\text { 四 } 1)^{5,6}$. これらの発 見により, ETではJAK2 あるいはMPLの変異によっ

*責任者連絡先 :

順天堂大学大学院医学研究科輸血. 幹細胞制御学

干 113-8421 東京都文京区本郷 2-1-1

Tel: 03-5802-1913, Fax: 03-3811-2724

E-mail: m-araki@juntendo.ac.jp
て MPL 下流の JAK2 シグナル伝達経路が恒常的に活 性化し（図 2), 異常な巨核球の増加と, それに伴う 血小板の増加が生じていることが明らかになった。 また MPL は, 巨核球のみならず造血幹細胞の維持や 増殖にも関与していることから ${ }^{7-9)}$, 変異を有する造 血幹細胞の腫瘍性増殖にも寄与していると考えられ ている.

\section{CALR 遺伝子変異の同定}

JAK2 変異と MPL 変異の発見により ET の分子病 態の解明が大きく進んだものの, 約半数の $\mathrm{ET}$ 症例 においてこれらの変異が見いだされなかった。その ため長期にわたって, MPL-JAK2 経路に関与する因 子の変異検索が行われたが, 決定的な変異は見いだ されず空振りに終わった. しかし2013 年末に, 高速 シークエンサーを用いた全エクソン配列解析により, JAK2 と MPL 変異が陰性の患者の約 $75 \%$ に共通し て，分子シャペロンをコードしている calreticulin （CALR）遺伝子に体細胞変異が見つかった ${ }^{10,11)}$. CALR は通常, 蛋白質分泌経路の出発点である小胞 体において, 将来細胞外に分泌される蛋白質や細胞 


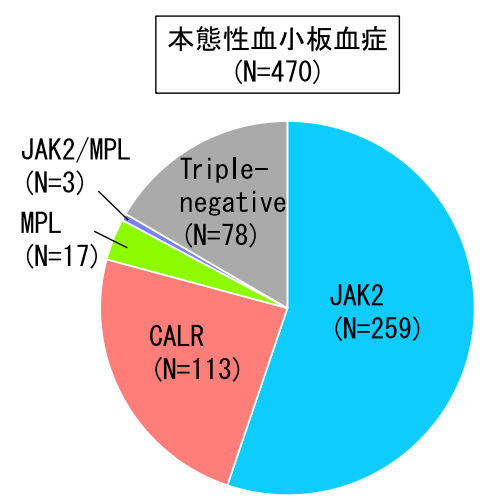

困 1 本態性血小板血症で見いだされる変異遺伝子

筆者らがWHO2016 分類に基づき本態性血小板血症と診断した患者の遺伝子変異頻度を記した. 3 例の患者が，2つの遺伝 子変異を有していた. Triple-negative は, JAK2, CALR, MPL 遺伝子のいずれにも変異が見いだされない症例である.

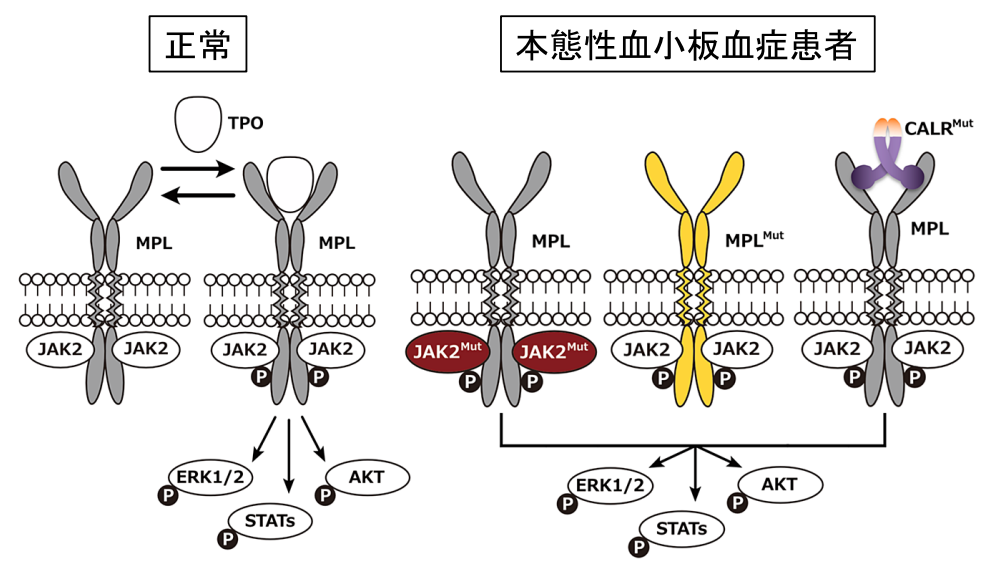

図 2 変異蛋白質による MPL 下流シグナルの活性化

文献（29）の図を改変して転載. 正常な状態では，TPOの有無により下流シグナルの調節が行われているが，本態性血小 板血症では, JAK2, MPL, あるいはCALRのいずれの変異型蛋白質も, TPOの無い環境でも下流のシグナル伝達経路を活 性化する.

膜に局在する受容体の折りたたみを促す分子シャぺ ロンとして働いている。 また, アポトーシスを起こ した細胞では細胞表面に出て, マクロファージによ る貪食を促進することが知られている．このため当 初, 変異型 CALR は, 受容体の成熟不全を引き起こす ことでMPL-JAK2 経路を活性化，あるいは抗腫瘍免疫 からの回避に関与し, ETを発症させるのではないかと 考えられた。一方で，分子シャペロンの異常がシグ ナル伝達経路の活性化を引き起こす事例が存在しな かったことや, 他の腫瘍で CALR 変異が報告されて いなかったことなどから，CALR 変異の報告を懐疑 的に感じたのは，筆者だけではなかったと想像する.
しかし, CALR変異の特徴が, この変異が偶然生 じたものではないことを強く物語っていた. CALR 変異は, 全てが最終エクソンの限定された領域にお ける短い塩基の挿入か欠失であり, 蛋白質に翻訳す るコドンの読み枠がずれるフレームシフト変異で あった。さらに, 通常の機能喪失型のフレームシフ 卜変異では，1あるいは 2 塩基の読み枠のずれがラ ンダムに生じるのに対し，ET患者で見いだされる CALR 変異の読み枠のずれは, 1 塩基だけであった. このため, CALR 変異遺伝子から産生される変異型 CALRのカルボキシル末端には, 変異型蛋白質に共 通する特異的なドメインが存在する（図3)。これら 

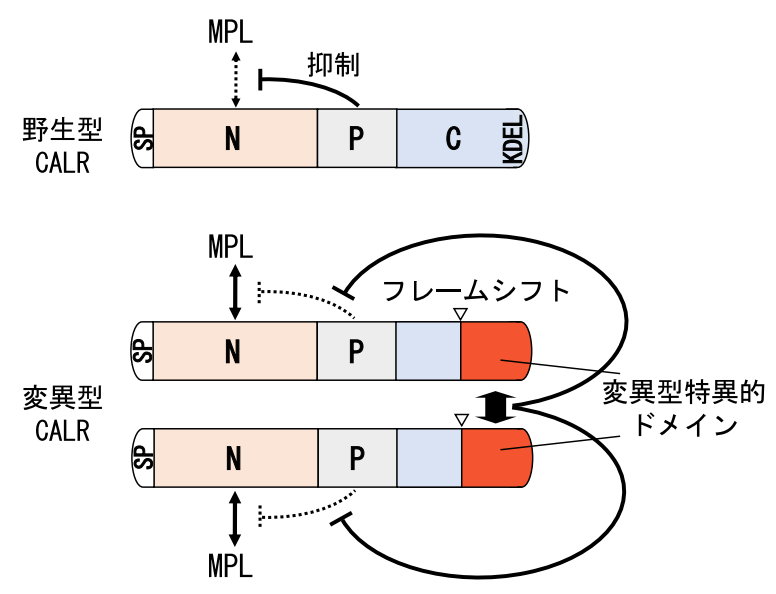

図 3 CALR蛋白質のドメイン構造

文献（21）の図を改変して転載. 野生型 CALRの構造は, 小胞体移行に必要なシグナルペプチド配列（SP）, N 型糖鎖結合 ドメイン $(\mathrm{N}), \mathrm{P}$ ドメイン, Cドメイン, 小胞体回帰シグナル (KDEL) に分けられる. 変異型 CALR は, フレームシフト 変異により, Cドメインの後半に変異型特異的ドメインが付加している。 このドメインは, 分子間相互作用によるホモ多 量体化を引き起こし，Nドメインを介した MPL との強固な結合に必要な構造変化を惹起していると考えられる.

のことから, CALR変異が機能獲得型の変異である ことが強く疑われた。

\section{CALR 変異遺伝子による血小板増多}

そこで筆者らは，ET患者において，JAK2，MPL， CALR 変異が相互排他的に見いだされることに着目 し, 野生型の JAK2 と MPL が機能している UT-7/TPO 細胞 ${ }^{12)}$ を用いて, 機能不明の CALR 変異遺伝子の 解析を行った。その結果，1）TPO依存性に増殖す る UT-7/TPO 細胞が, CALR 変異遺伝子の発現によ り TPO 非依存性に増殖すること, 2) この際に, MPL 下流の JAK2 の活性化が生じていること，3）変異型 CALR 依存性の細胞増殖に MPL が必要であること, が明らかになった ${ }^{13)}$ 。また他のグループから同様の 研究結果に加えて ${ }^{14,15)}$, CALR 変異遺伝子を発現さ せた造血幹細胞を放射線照射したマウスに移植する と，骨髄中における巨核球の増加，それに伴う末梢 血中の血小板の増多が観察され, ET の病態が再現さ れることや ${ }^{14,16)}$ ，トランスジェニックマウスやノッ クインマウスでも同様の結果が報告された ${ }^{17,18)}$ 。一 方筆者らは, CALR 変異陽性の患者から樹立したiPS 細胞を造血幹・前駆細胞に誘導すると, TPO 非依存 性に巨核球に分化すること，さらにこの分化に MPL
が必須であることを示した ${ }^{13,19)}$.これらのことか ら, 変異型 CALR が未知の機能で MPLを恒常的に 活性化させることで巨核球の増加を引き起こし, ET を発症させることが明らかになった

(四 2)

\section{4. フレームシフト変異により出現した変異型特 異的ドメインの役割}

次に筆者らは, 変異型 CALR によるMPL の特異 的な活性化が生じる分子メカニズムを明らかにする ために生化学的な解析を行い, 変異型 CALR が MPL と強固に結合することを見出した ${ }^{13)}$. そして変異型 CALRには，フレームシフト変異により生まれた変 異型特異的なドメインが存在することから, このド メインが MPLの結合ドメインと考えて解析を続けた が, 結合は全く検出できなかった。 そこで変異型 CALRの様々な欠失変異体を作成して結合試験を 行ったところ，1）野生型にも存在する Nドメイン がMPL との結合を担っていること，2）野生型 CALR ではN N゙メインによる MPL との結合が P ドメイン により抑制されていること，3）変異型 CALRでは この抑制が変異型特異的ドメインにより解除され るため MPL と結合できること，が明らかになった (図 3 $)^{13)}$ 。これにより変異型 CALRが，野生型では 
見られないMPL との強い結合能を獲得し，MPLの 活性化を引き起こしていると考えられたが, 依然と して MPL の活性化を引き起こす分子メカニズムは不 明であった。

MPL の含まれるI型サイトカイン受容体は, 細胞 外ドメインにサイトカインが結合してホモ 2 量体化 し，受容体の細胞内ドメインに結合したチロシンキ ナーゼが相互をリン酸化することで，活性化する (図 2 左)。そこで筆者は，変異型 CALRがMPL の 2 量体化を引き起すモデルとして, 変異型 CALR のホ モ2量体化を考えた。これは，2つの MPL 結合ドメ インを有する 1 つの変異型ホモ 2 量体が，2 分子の MPL と結合することで, MPLのホモ 2 量体化を引き 起こすというモデルである。これを検証するために 生化学的な解析を行い, 変異型 CALR が分子間相互 作用によりホモ多量体を形成することを明らかに した ${ }^{20)}$ 。ささらに解析を進めたところ, 変異型 CALR 同士の分子間相互作用は，フレームシフト変異によ り生じた変異型特異的ドメインで生じていることが 明らかになった。また，このような変異型 CALRの ホモ多量体化を阻害すると, MPL との結合や活性化 が著しく低下することが明らかになった ${ }^{20)}$ 。これら のことは, 変異型特異的ドメインにおけるホモ多量 体化が構造変化を引き起こし, 先に述べた P ドメイ ンによる MPL 結合抑制を，解除していることを強く 示唆している $(\text { 龱 3 })^{21)}$. 以上の解析により, 変異型 CALR は MPLのリガンドのように働いて，MPLの 活性化を引き起こしていることが明らかになった (図 2)。

\section{5. 変異型 CALR による CALR 変異陽性細胞選択 的な MPL 活性化}

次に筆者らは，変異型 CALR が，TPO と同じよう に細胞外から細胞表面に発現している MPLを活性 化する可能性について検討した。変異型 CALRは, フレームシフト変異により, 野生型 CALRのカルボ キシル末端に存在する小胞体回帰シグナルが墠失す るため（図 3)，細胞外に分泌される ${ }^{22)}$ ，そこで変異 型 CALR を分泌する細胞と, MPLを発現する UT-7/TPO 細胞を共培養して増殖を調べたが, 分泌さ
れた変異型 CALR は UT-7/TPO 細胞の表面に発現す る MPL を活性化しなかった ${ }^{13)}$ 。これは, 変異型 CALRが MPL のリガンドのように振る舞うというモ デルと一見矛盾する結果であるが, CALR変異細胞 の MPL を選択的に活性化することから, CALR 変異 陽性患者で見られる腫瘍細胞の増殖優位性とは合致 している.

このような変異型 CALRによる, CALR 変異陽性 細胞に特異的な MPLの活性化が生じる背景には, MPLの成熟の違いがある. 先述のとおり, 野生型 CALR は小胞体内で受容体などの分子の折りたたみ に関与しているが，折りたたみを行う必要のある新 たに合成された蛋白質を識別する必要がある。この 識別には，標的蛋白質のアスパラギン（N）残基に 付加された $\mathrm{N}$ 型糖鎖の成熟が関与しており, 未成 熟な場合にのみ CALRが結合し，折りたたみが終了 し N 型糖鎖が成熟すると結合できなくなる（図 4 左 下 $)^{23)}$.この $\mathrm{N}$ 型糖鎖結合能は, 変異型 CALRにお いて MPL 結合を担っている N ドメインに存在し, N 型糖鎖結合部位を破壊すると MPL との結合や活性 化ができなくなる ${ }^{15,24,25)}$. これらのことは, 変異型 CALRが，野生型 CALRに備わっていた未成熟な N 型糖鎖結合能を使って MPL と結合していることを示 している（図 4)。そのため, 通常の細胞表面に発現 している成熟したN 型糖鎖を有する MPL に結合で きないことから, 通常の細胞に対しては, サイトカ インのように働かない（図 5).

\section{6. 変異型 CALR による MPL の活性化が生じる 場所}

次に筆者らは，変異型 CALR によるMPL の活性 化が生じる細胞内での場所を調べた. 先述のとおり, 変異型 CALR は細胞外に分泌されることから, CALR 変異を有する細胞において未成熟な $\mathrm{N}$ 型糖鎖を有す るMPL が細胞表面に発現していれば，それを autocrine に活性化する可能性が考えられる。一方で, 小胞体で変異型 CALR と MPL が結合して複合体を 形成し, 細胞内で活性化する可能性もある。 そこで 筆者らは，蛋白質の細胞表面への輸送や細胞外への 分泌を阻害したときの MPL の活性化状態を調べ, 変 


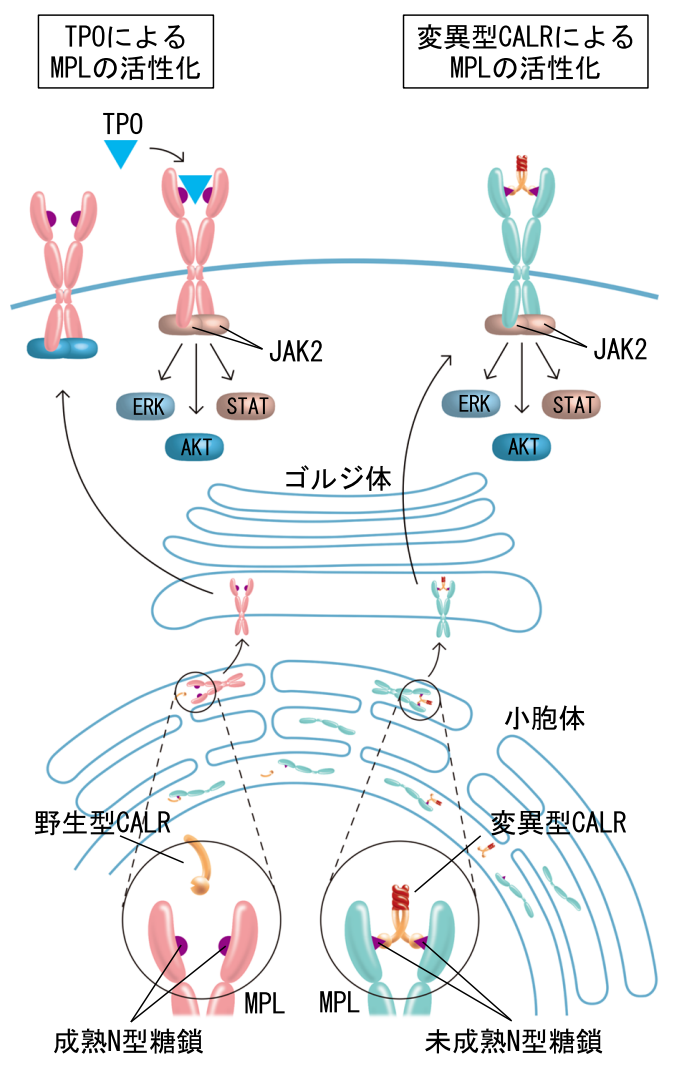

図 4 変異型 CALR による MPL の活性化メカニズム

文献（30）の図を改変して転載. 分子シャペロンである野生型 CALR は，未成熟な N 型糖鎖を認識して MPLと結合し， MPLの折りたたみの完了に伴う N 型糖鎖の成熟により, MPL から解離する。一方で, 変異型 CALR は MPL と強固な複合 体を形成し，小胞体回帰シグナルを亦失しているために（図3），ゴルジ体を経由して細胞表面まで移行し，下流のシグナ ル伝達経路を活性化する。

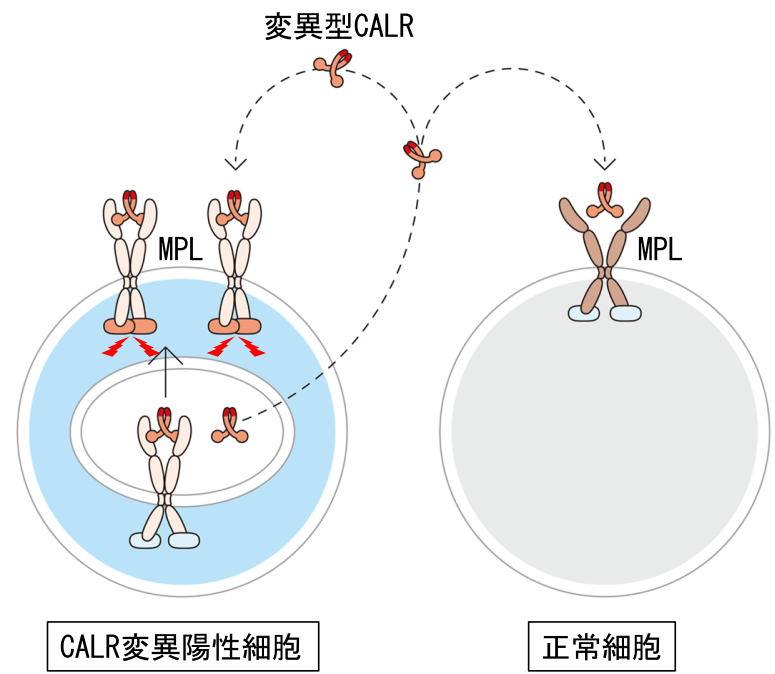

龱 5 変異型 CALR による CALR 変異細胞選択的な MPL 活性化

文献（31）の図を改変して転載. 変異型 CALR は, 正常細胞表面の成熟型 MPL を活性化せず, CALR 変異細胞で発現して いるMPLを活性化する。分泌された変異型 CALRが, CALR 変異細胞表面の MPLを活性化できることが示されている. 一方で, 細胞内で形成された変異型 CALR C M の 複合体も細胞表面で活性化していると考えられることから, 分泌され た変異型 CALRによる活性化が患者細胞でどの程度生じているかは未解明である。 
異型 CALRによる MPL の活性化が，輸送や分泌の 阻害に対して耐性であることを見出した ${ }^{24)}$ 。これ は，細胞内で変異型 CALR と MPL が複合体を形成 し，細胞表面に到達する前に，活性化していること を示唆していた。これを確認するために筆者らは, 細胞表面の蛋白質をプロテアーゼにより取り除いて, MPL 下流の活性化状態を調べたが，予想に反して， 活性化は速やかに消失した。また，変異型 CALR を発現する細胞の表面における MPL の挙動を調べた ところ，本来のリガンドである TPO で惹起されるよ うな迅速な細胞内への移行（internalization）は観察 されず，長時間にわたって細胞表面に存在している ことが明らかになった。これらのことから，変異 型 CALR の結合した MPL は，細胞表面において持 続的に活性化していることが明らかになった（図4, 図 5$)^{24)}$ 。なお, 細胞表面で MPL を活性化する変異 型 CALR が，細胞内から MPL と結合していたもの であるのか，細胞外に分泌されたものが結合したの かについては不明であるが，細胞外に分泌された変 異型 CALR がCALR 変異細胞表面の MPL を活性化 できることは示されている(図 5 $)^{26)}$.

本稿で紹介したように, 分子シャペロンの異常が, 当初は全く想像もしていなかった分子メカニズムで 受容体のリガンドとしての機能を獲得し, 細胞の腫 瘍化を引き起こしていることが明らかになった。し かし, 変異型 CALRの細胞内動態には不明な点も多 く, 分子構造も解明されていないことから，今後の 解析により，さらなる驚きの発見があるかもしれな い.また最近になって，変異型 CALRが核内での転 写調節 ${ }^{27)}$ や，細胞外での免疫抑制に関与する ${ }^{28)}$ と の報告がなされている，今後，CALR変異による血 小板増多の分子病態の解明がさらに進むことで，新 たな治療法が開発されることを期待したい.

\section{著者の利益相反 $(\mathrm{COI})$ の開示 :}

本論文発表内容に関連して開示すべき企業等との利 益相反なし

\section{文献}

1) Levine RL, Wadleigh M, Cools J, Ebert BL, Wernig G, Huntly BJ, Boggon TJ, Wlodarska I, Clark JJ, Moore S, Adelsperger J, Koo S, Lee JC, Gabriel S, Mercher T, D'
Andrea A, Frohling S, Dohner K, Marynen P, Vandenberghe P, Mesa RA, Tefferi A, Griffin JD, Eck MJ, Sellers WR, Meyerson M, Golub TR, Lee SJ, Gilliland DG: Activating mutation in the tyrosine kinase JAK2 in polycythemia vera, essential thrombocythemia, and myeloid metaplasia with myelofibrosis. Cancer Cell 7: 387-397, 2005.

2) Kralovics R, Passamonti F, Buser AS, Teo SS, Tiedt R, Passweg JR, Tichelli A, Cazzola M, Skoda RC: A gain-offunction mutation of JAK2 in myeloproliferative disorders. N Engl J Med 352: 1779-1790, 2005.

3) James C, Ugo V, Le Couedic JP, Staerk J, Delhommeau F, Lacout C, Garcon L, Raslova H, Berger R, BennaceurGriscelli A, Villeval JL, Constantinescu SN, Casadevall N, Vainchenker W: A unique clonal JAK2 mutation leading to constitutive signalling causes polycythaemia vera. Nature 434: 1144-1148, 2005.

4) Baxter EJ, Scott LM, Campbell PJ, East C, Fourouclas N, Swanton S, Vassiliou GS, Bench AJ, Boyd EM, Curtin N, Scott MA, Erber WN, Green AR: Acquired mutation of the tyrosine kinase JAK2 in human myeloproliferative disorders. Lancet 365: 1054-1061, 2005.

5) Pikman Y, Lee BH, Mercher T, McDowell E, Ebert BL, Gozo M, Cuker A, Wernig G, Moore S, Galinsky I, DeAngelo DJ, Clark JJ, Lee SJ, Golub TR, Wadleigh M, Gilliland DG, Levine RL: MPLW515L is a novel somatic activating mutation in myelofibrosis with myeloid metaplasia. PLoS Med 3: e270, 2006.

6) Pardanani $A D$, Levine RL, Lasho T, Pikman Y, Mesa RA, Wadleigh M, Steensma DP, Elliott MA, Wolanskyj AP, Hogan WJ, McClure RF, Litzow MR, Gilliland DG, Tefferi A: MPL515 mutations in myeloproliferative and other myeloid disorders: a study of 1182 patients. Blood 108: 3472-3476, 2006.

7) Kovtonyuk LV, Manz MG, Takizawa H: Enhanced thrombopoietin but not G-CSF receptor stimulation induces self-renewing hematopoietic stem cell divisions in vivo. Blood 127: 3175-3179, 2016.

8) Yoshihara H, Arai F, Hosokawa K, Hagiwara T, Takubo K, Nakamura Y, Gomei Y, Iwasaki H, Matsuoka S, Miyamoto K, Miyazaki H, Takahashi T, Suda T: Thrombopoietin/MPL signaling regulates hematopoietic stem cell quiescence and interaction with the osteoblastic niche. Cell Stem Cell 1: 685697, 2007.

9) Qian H, Buza-Vidas N, Hyland CD, Jensen CT, Antonchuk J, Mansson R, Thoren LA, Ekblom M, Alexander WS, Jacobsen SE: Critical role of thrombopoietin in maintaining adult quiescent hematopoietic stem cells. Cell Stem Cell 1: 671684, 2007.

10) Nangalia J, Massie CE, Baxter EJ, Nice FL, Gundem G, Wedge DC, Avezov E, Li J, Kollmann K, Kent DG, Aziz A, Godfrey AL, Hinton J, Martincorena I, Van Loo P, Jones AV, Guglielmelli P, Tarpey P, Harding HP, Fitzpatrick JD, Goudie CT, Ortmann CA, Loughran SJ, Raine K, Jones DR, Butler AP, Teague JW, O'Meara S, McLaren S, Bianchi M, Silber Y, Dimitropoulou D, Bloxham D, Mudie L, Maddison M, Robinson B, Keohane C, Maclean C, Hill K, Orchard K, Tauro S, Du MQ, Greaves M, Bowen D, Huntly BJ, Harrison CN, Cross NC, Ron D, Vannucchi AM, Papaemmanuil E, Campbell PJ, Green AR: Somatic CALR mutations in 
myeloproliferative neoplasms with nonmutated JAK2. N Eng1 J Med 369: 2391-2405, 2013.

11) Klampfl $T$, Gisslinger $H$, Harutyunyan AS, Nivarthi H, Rumi E, Milosevic JD, Them NC, Berg T, Gisslinger B, Pietra D, Chen D, Vladimer GI, Bagienski K, Milanesi C, Casetti IC, Sant'Antonio E, Ferretti V, Elena C, Schischlik F, Cleary C, Six M, Schalling M, Schonegger A, Bock C, Malcovati L, Pascutto C, Superti-Furga G, Cazzola M, Kralovics R: Somatic mutations of calreticulin in myeloproliferative neoplasms. N Engl J Med 369: 2379-2390, 2013.

12) Komatsu N, Kunitama M, Yamada M, Hagiwara T, Kato T, Miyazaki H, Eguchi M, Yamamoto M, Miura Y: Establishment and characterization of the thrombopoietindependent megakaryocytic cell line, UT-7/TPO. Blood 87: 4552-4560, 1996.

13) Araki M, Yang $Y$, Masubuchi N, Hironaka $Y$, Takei H, Morishita S, Mizukami Y, Kan S, Shirane S, Edahiro Y, Sunami Y, Ohsaka A, Komatsu N: Activation of the thrombopoietin receptor by mutant calreticulin in CALRmutant myeloproliferative neoplasms. Blood 127: 1307-1316, 2016.

14) Elf S, Abdelfattah NS, Chen E, Perales-Paton J, Rosen EA, Ko A, Peisker F, Florescu N, Giannini S, Wolach O, Morgan EA, Tothova Z, Losman JA, Schneider RK, Al-Shahrour F, Mullally A: Mutant Calreticulin Requires Both Its Mutant Cterminus and the Thrombopoietin Receptor for Oncogenic Transformation. Cancer Discov 6: 368-381, 2016.

15) Chachoua I, Pecquet C, El-Khoury M, Nivarthi H, Albu RI, Marty C, Gryshkova V, Defour JP, Vertenoeil G, Ngo A, Koay A, Raslova H, Courtoy PJ, Choong ML, Plo I, Vainchenker W, Kralovics R, Constantinescu SN: Thrombopoietin receptor activation by myeloproliferative neoplasm associated calreticulin mutants. Blood 127: 1325-1335, 2016.

16) Marty C, Pecquet C, Nivarthi H, El-Khoury M, Chachoua I, Tulliez M, Villeval JL, Raslova H, Kralovics R, Constantinescu SN, Plo I, Vainchenker W: Calreticulin mutants in mice induce an MPL-dependent thrombocytosis with frequent progression to myelofibrosis. Blood 127: 13171324, 2016.

17) Li J, Prins D, Park HJ, Grinfeld J, Gonzalez-Arias C, Loughran S, Dovey OM, Klampfl T, Bennett C, Hamilton TL, Pask DC, Sneade R, Williams M, Aungier J, Ghevaert C, Vassiliou GS, Kent DG, Green AR: Mutant calreticulin knockin mice develop thrombocytosis and myelofibrosis without a stem cell self-renewal advantage. Blood 131: 649661,2018

18) Shide K, Kameda T, Yamaji T, Sekine M, Inada N, Kamiunten A, Akizuki K, Nakamura K, Hidaka T, Kubuki Y, Shimoda H, Kitanaka A, Honda A, Sawaguchi A, Abe H, Miike T, Iwakiri H, Tahara Y, Sueta M, Hasuike S, Yamamoto S, Nagata K, Shimoda K: Calreticulin mutant mice develop essential thrombocythemia that is ameliorated by the JAK inhibitor ruxolitinib. Leukemia 31: 1136-1144, 2017.

19) Takei H, Edahiro $Y$, Mano $S$, Masubuchi N, Mizukami $Y$, Imai M, Morishita S, Misawa K, Ochiai T, Tsuneda S, Endo H, Nakamura S, Eto K, Ohsaka A, Araki M, Komatsu N: Skewed megakaryopoiesis in human induced pluripotent stem cell- derived haematopoietic progenitor cells harbouring calreticulin mutations. Br J Haematol 181: 791-802, 2018.

20) Araki M, Yang Y, Imai M, Mizukami Y, Kihara Y, Sunami Y, Masubuchi N, Edahiro Y, Hironaka Y, Osaga S, Ohsaka A, Komatsu N: Homomultimerization of mutant calreticulin is a prerequisite for MPL binding and activation. Leukemia 33: 122-131, 2019.

21) Araki M, Komatsu N: Mutant molecular chaperone activates cytokine receptor as a homomultimer. Oncotarget 9: 3520135202, 2018.

22) Han L, Schubert C, Kohler J, Schemionek M, Isfort S, Brummendorf TH, Koschmieder S, Chatain N: Calreticulinmutant proteins induce megakaryocytic signaling to transform hematopoietic cells and undergo accelerated degradation and Golgi-mediated secretion. J Hematol Oncol 9: 45, 2016.

23) Peterson JR, Ora A, Van PN, Helenius A: Transient, lectinlike association of calreticulin with folding intermediates of cellular and viral glycoproteins. Mol Biol Cell 6: 1173-1184, 1995.

24) Masubuchi N, Araki M, Yang Y, Hayashi E, Imai M, Edahiro Y, Hironaka Y, Mizukami Y, Kihara Y, Takei H, Nudejima M, Koike M, Ohsaka A, Komatsu N: Mutant calreticulin interacts with MPL in the secretion pathway for activation on the cell surface. Leukemia 34: 499-509, 2020.

25) Elf S, Abdelfattah NS, Baral AJ, Beeson D, Rivera JF, Ko A, Florescu N, Birrane G, Chen E, Mullally A: Defining the requirements for the pathogenic interaction between mutant calreticulin and MPL in MPN. Blood 131: 782-786, 2018.

26) Pecquet $\mathrm{C}$, Balligand $\mathrm{T}$, Chachoua I, Roy A, Vertenoeil G, Colau D, Fertig E, Marty C, Nivarthi H, Defour JP, Xu E, Hug E, Gisslinger H, Gisslinger B, Schalling M, Casetti IC, Rumi E, Pietra D, Cavalloni C, Arcaini L, Cazzola M, Komatsu N, Kihara Y, Sunami Y, Edahiro Y, Araki M, Plo I, Vainchenker W, Kralovics R, Constantinescu SN: Secreted Mutant Calreticulins As Rogue Cytokines Trigger Thrombopoietin Receptor Activation Specifically in CALR Mutated Cells: Perspectives for MPN Therapy. Blood 132 (Supplement 1): 4, 2018.

27) Pronier E, Cifani P, Merlinsky TR, Berman KB, Somasundara AV. H, Rampal RK, LaCava J, Wei KE, Pastore F, Maag JL, Park J, Koche R, Kentsis A, Levine RL: Targeting the CALR interactome in myeloproliferative neoplasms. JCI Insight 3: 2018.

28) Liu P, Zhao L, Loos F, Marty C, Xie W, Martins I, Lachkar S, Qu B, Waeckel-Enee E, Plo I, Vainchenker W, Perez F, Rodriguez D, Lopez-Otin C, van Endert P, Zitvogel L, Kepp O, Kroemer G: Immunosuppression by Mutated Calreticulin Released from Malignant Cells. Mol Cell 77: 748-760 e749, 2020.

29) 荒木真理人, 森下総司, 小松則夫 : 骨髄増殖性腫瘍の遺 伝子変異 最近の知見. 臨床血液 57: 2526-2534, 2016.

30) Edahiro Y, Araki M, Komatsu N: Mechanism underlying the development of myeloproliferative neoplasms through mutant calreticulin. Cancer Sci 111: 2682-2688, 2020.

31) Araki M, Komatsu N: The role of calreticulin mutations in myeloproliferative neoplasms. Int J Hematol 111: 200-205, 2020. 